\title{
A Rapid Method for the Determination of Radio- active Caesium in Live Animals and Carcasses, and its Practical Application in Norway after the Chernobyl Nuclear Reactor Accident
}

\author{
By L. I. Brynildsen ${ }^{1,2}$ and P. Strand ${ }^{3}$
}

${ }^{1}$ Ministry of Agriculture, Division of Veterinary Services, and ${ }^{2}$ Norwegian College of Veterinary Medicine, Department of Food Hygiene, Oslo, and ${ }^{3}$ Norwegian Radiation Protection Authorithy, Østerås, Norway.

\begin{abstract}
Brynildsen, L. I. and P. Strand: A rapid method for the determination of radioactive caesium in live animals and carcasses, and its practical application in Norway after the Chernobyl nuclear reactor accident. Acta vet. scand. 1994, 35, 401-408. - A technique was developed for the measurement of levels of caesium radionuclides $\left({ }^{137} \mathrm{Cs}+{ }^{134} \mathrm{Cs}\right)$ in live reindeer, cattle, and sheep and in carcasses from these species. The instrument used was a sodium iodide scintillation detector coupled to a portable multi-channel analyser.

Based on a combination of background measurements and measurements of impulses from animals with the detector in different anatomical positions we recommmend the following procedures: Lamb: The detector placed on os sacrum (standing animal). Reindeer: The detector placed between the hind legs (animal lying on its side). Cattle: The detector placed on the back of the standing animal, midway between os sacrum and trochanter major.

Average geometrical factors for live animals were estimated. It was a linear correlation between measured activity levels in meat samples and counted impulses per sec in live animals. Geometrical factors were estimated at $95 \%$ confidence level with uncertainty between $6-14 \%$. The detection limits varied between $50-200 \mathrm{~Bq}$ (becquerel) $/ \mathrm{kg}$ in areas with ground depositions between $5-200 \mathrm{kBq} / \mathrm{m}^{2}$. Since the winter $1986 / 87$ the technique has been the standard procedure for monitoring slaughter animals and carcasses for radiocaesium activity concentrations.
\end{abstract}

live monitoring; radiocaesium.

\section{Introduction}

After the Chernobyl nuclear reactor accident on April 261986 it soon became clear that levels of radiocaesium in Norwegian foodstuffs were among the highest in Western Europe. This was particulary the case in meat from reindeer, sheep, and cattle in certain districts, as well as in game meat, goats milk, fungi, and wild freshwater fish (Strand et al. 1989).

Intervention levels for the radioactive isotopes of caesium $\left({ }^{137} \mathrm{Cs}+{ }^{134} \mathrm{Cs}\right)$ in foodstuffs were established in June 1986 to $370 \mathrm{~Bq} / \mathrm{kg}$ for milk and baby food, and to $600 \mathrm{~Bq} / \mathrm{kg}$ for all other foodstuffs. In November 1986, the intervention level for reindeer and game meat was raised to $6000 \mathrm{~Bq} / \mathrm{kg}$.

In 1986 rapid methods for measurements on live animals were not availible. In connection with the slaughtering season in the autumn 1986, measurements on meat samples were carried out to map the areas of the country in which radioactive levels in meat from reindeer, 
sheep, and cattle exceeded the intervention levels. The collection and measurement of meat samples was a labour-intensive and costly process. Despite the introduction of effective countermeasures, substantial quantities of sheep meat had to be condemned as meat for human consumption, sheep meat valued at NOK 80 mill. (Johanson \& Brynildsen 1988).

Measurement of radioactivity in live animals would allow the separation of animals which would require special feeding programs.

Similar measurements on carcasses would allow meat to be approved or condemned on site. The present paper describes the development of a technique for monitoring live animals and carcasses. An abstract of the method has been published earlier (Strand \& Brynildsen 1989). The described technique has been the standard method in Norway since 1986/87. Later similar methods have also been developed and used in other countries (Colgan et al. 1989).

\section{Materials and methods}

Two series of experiments are reported. Initial experiments in 1986/87 on reindeer, sheep and cattle (series 1). Additional experiments on sheep in 1988 (series 2).

\section{Series 1}

Measurements on reindeer were carried out during the last months of 1986 , followed by measurements on cattle and sheep during the first months of 1987. The material included live reindeer, cattle, and sheep, as well as carcasses and samples of meat derived from the same individual (Table 1 and 2). The original intention was to include a larger material, but difficulties associated with the practical implementation of the trial resulted in data from fewer animals and carcasses than planned.

\section{Series 2}

In 1988 a second trial was performed, involv- ing 38 sheep from 7 places with background levels ranging from $5 \mathrm{kBq} / \mathrm{m}^{2}$ to $200 \mathrm{kBq} / \mathrm{m}^{2}$. Personell from the field service in contaminated districts used their own equipment to carry out the measurements. This design was chosen to give realistic estimation of the uncertainty of the method (Table 3).

\section{Measuring equipment}

A portable, battery operated Canberra Series 10 multi-channel analyser (Canberra, 06450 Connecticut, USA), together with a 3" 3 3" NaI crystal detector (Harshaw, Netherlands) was used. To reduce the sensitivity to harsh environmental conditions (rain, snow) the detector was protected in a cylindrical plastic shield. The shield also served to stabilise the apparatus and give mechanical protection.

\section{Measuring procedures}

Series 1: Radiocaesium was first measured in live animals and in carcasses. Activity levels of ${ }^{137} \mathrm{Cs}$ and ${ }^{134} \mathrm{Cs}$ in the meat from the same animals were determined on $250 \mathrm{~g}$ samples with the NaI detector in a lead shield, (AndersonSörli et al. 1992).

The measuring equipment was calibrated for in vivo measurements by applying the ratio between the activity in the meat sample $250 \mathrm{~g}$ (A), and the recorded number of net-impulses per sec for ${ }^{137} \mathrm{Cs}$ and ${ }^{134} \mathrm{Cs}$ from the in vivo determination (I). This ratio was termed the geometrical factor $(\mathrm{G}), \mathrm{G}=\mathrm{A} / \mathrm{I}$. A corresponding equation was applied when determining activity levels in carcasses.

In order to measure the background radiation the detector was held freely in the air at the same position and level above ground as the measurement site on the animal species in question. Counts in the energy range for ${ }^{137} \mathrm{Cs}$ and ${ }^{134} \mathrm{Cs}$ were recorded.

When the detector was held against an animal, the body of the animal would partly 
Table 1. Estimated mean geometrical factor $(\mathrm{G})$, and $95 \%$ confidence levels for measurements of ${ }^{137} \mathrm{Cs}+{ }^{134} \mathrm{Cs}$ in live reindeer, cattle, and sheep (Series 1).

\begin{tabular}{lclc}
\hline $\begin{array}{l}\text { Animal } \\
\text { species }\end{array}$ & $\begin{array}{c}\text { Number } \\
\text { of animals }\end{array}$ & Age & G \\
\hline Reindeer & 5 & $\begin{array}{l}\text { calf } \\
\text { (November) }\end{array}$ & $14.7 \pm 0.9$ \\
Cattle & 10 & $\begin{array}{l}\text { adult cow } \\
\text { adult bull }\end{array}$ & $12.8 \pm 1.8$ \\
& 12 & adult & $34.6 \pm 2.3$ \\
Sheep & 14 & & \\
(shorn) & & & \\
\hline
\end{tabular}

Table 2. Estimated mean geometrical factor (G and $95 \%$ confidence levels for measurements of ${ }^{137} \mathrm{Cs}+{ }^{134} \mathrm{Cs}$ in carcasses of reindeer, cattle, and sheep (Series 1).

\begin{tabular}{lclr}
\hline $\begin{array}{l}\text { Animal } \\
\text { species }\end{array}$ & $\begin{array}{r}\text { Number } \\
\text { of animals }\end{array}$ & Age & G \\
\hline Reindeer & 31 & calf & $12.1 \pm 0.5$ \\
& 3 & yearling & $\begin{array}{r}10.9 \pm 0.8 \\
\text { Cattle }\end{array}$ \\
& 3 & adult & $9.4 \pm 0.8$ \\
Sheep & 9 & adult cow & $8.3 \pm 0.6$ \\
\hline
\end{tabular}

Table 3. Estimated mean geometrical factor (G), and $95 \%$ confidence levels for measurements of ${ }^{137} \mathrm{Cs}+{ }^{134} \mathrm{Cs}$ i live sheep (Series 2).

\begin{tabular}{lclc}
\hline $\begin{array}{l}\text { Animal } \\
\text { species }\end{array}$ & $\begin{array}{c}\text { Number } \\
\text { of animals }\end{array}$ & Age & G \\
\hline Sheep & 38 & adult & $22.6 \pm 1.5$ \\
\hline
\end{tabular}

Table 4. Geometrical factors used in 1993 for measurements of radioactivity levels in live reindeer, cattle, and sheep.

\begin{tabular}{llc}
\hline Animal species & Age & G \\
\hline Reindeer & adult & 12 \\
& calf & $14-17$ \\
Cattle & adult & 12 \\
Sheep & adult & 25 \\
(non shorn) & lamb & $25-32$ \\
\hline
\end{tabular}

shield the detector from background radiation. A shielding factor could be established which expressed the proportion of the background radiation not absorbed. The shielding factor for sheep in series 1 was estimated on the basis of measurements of almost uncontaminated animals. For reindeer a model of the hind legs was made by help of rubber tire filled with water.

The instrument was programmed with an equation which took into consideration the counts, geometrical factor, shielding factor and background radiation. The combined activity level of ${ }^{137} \mathrm{Cs}$ and ${ }^{134} \mathrm{Cs}$ could be read directly from the display on the instrument. Time taken for measurement was usually between 30 and $60 \mathrm{sec}$.

High background radiation could create measuring problems. For control purposes, socalled phantom animals, i.e. containers filled with solutions equalling the invention level in question were used to check the accuracy of the method on places with high background radiation prior to measurements of animals.

\section{Site of measurement in the live animal}

Various sites for placement of the detector were tested in order to find sites which were subject to the least interference from background radiation, and which upset the animal to the least possible extent.

Reindeer were placed on the side and the detector was positioned against the ventral part of the pelvis (os pubis) between and parallell with the hind legs (Fig. 1).

In cattle, the detector was placed over the pelvis of the standing animal midway between the tuber coxae and the tuber ischii, and midway between the os sacrum and trochanter major. Beneath this site lies the gluteo-biceps muscle and the gluteus medius (sirloin). The detector was held at an angle of about $45^{\circ}$ to a vertical line in the animal's sagittal plane (Fig. 2). 


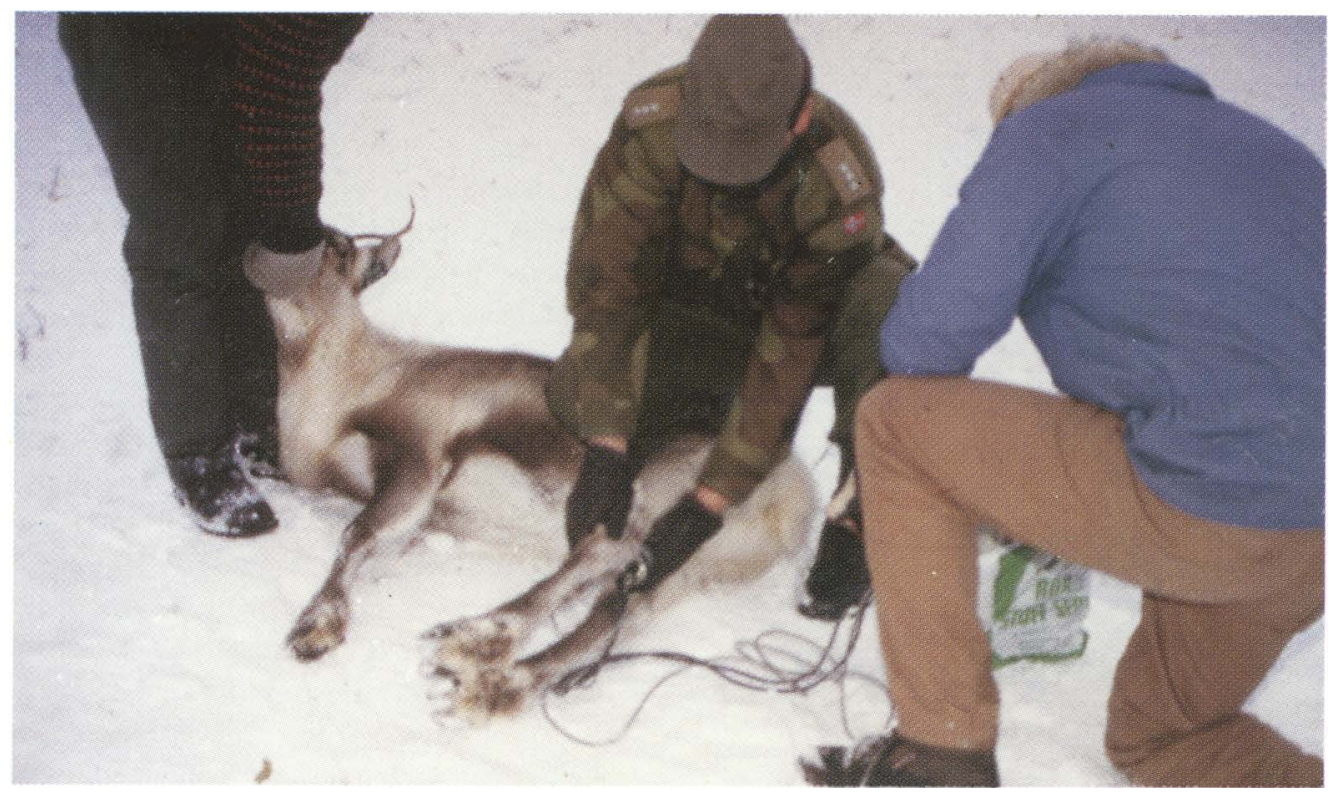

Figure 1. Measurement of radioactive caesium in live reindeer.

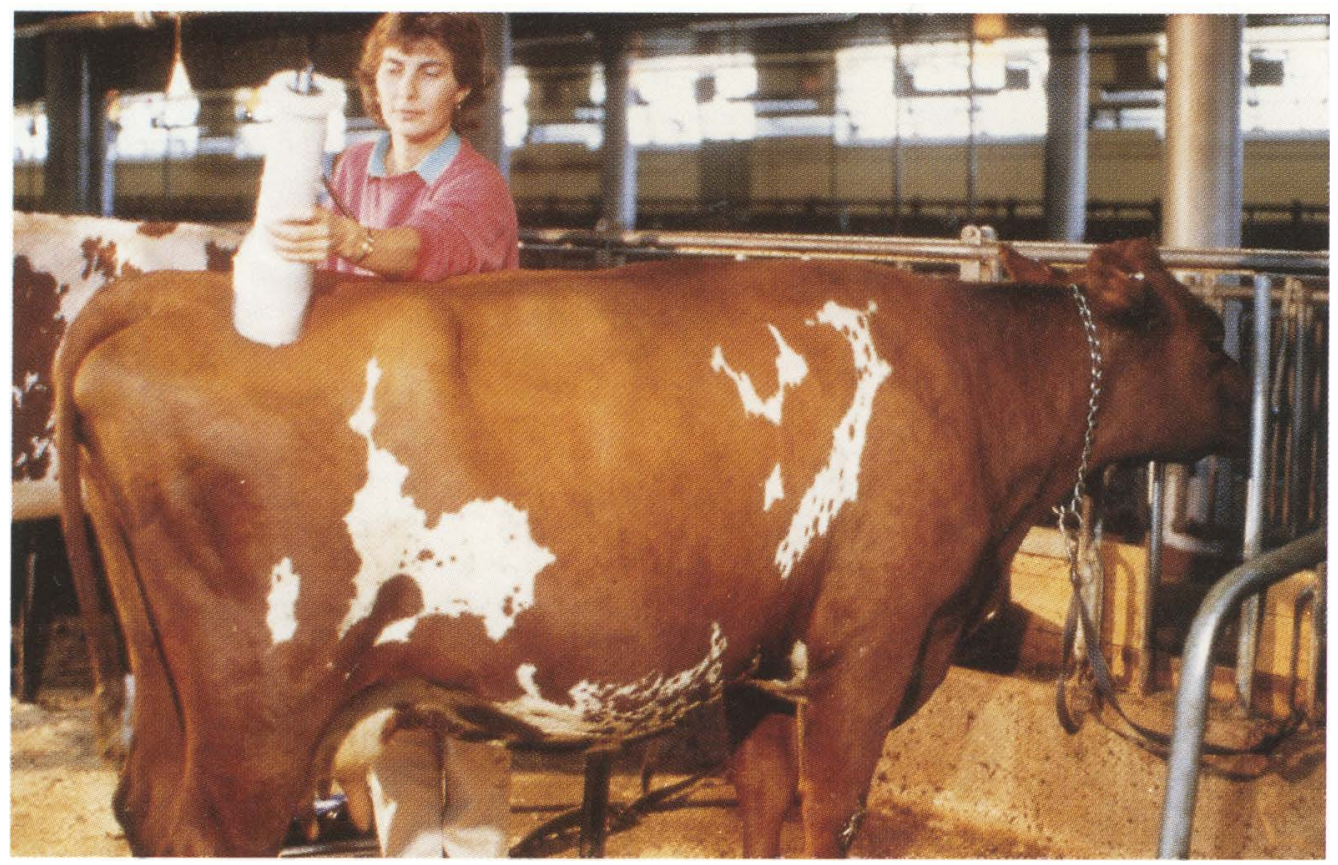

Figure 2. Measurement of radioactive caesium in live cattle. 


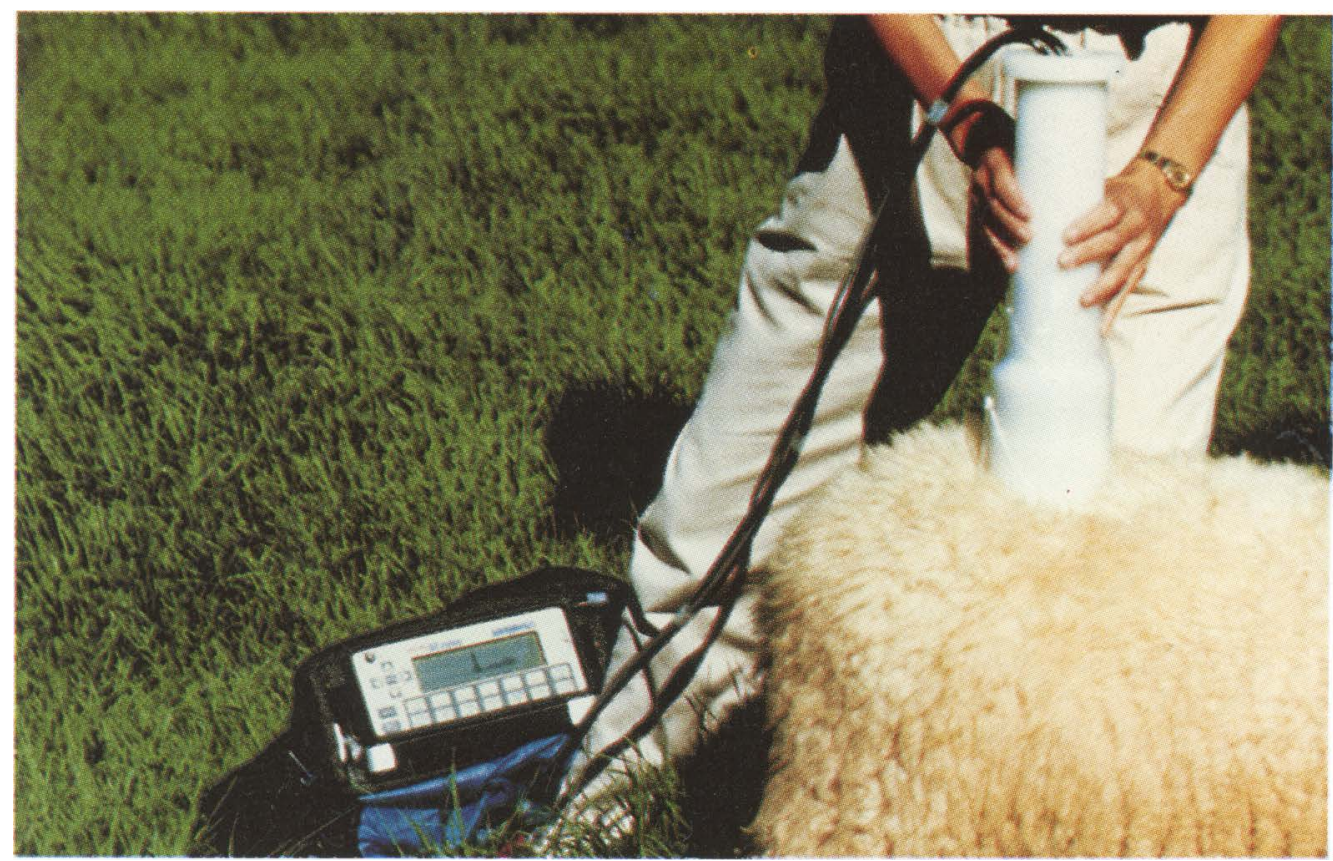

Figure 3. Measurement of radioactive caesium in live sheep.

In sheep, the wool was removed from the measuring site. The detector was held vertically against os sacrum on the standing animal. Using a straight line between the 2 tuber coxae, the detector was placed behind the line with an overlap of $1 \mathrm{~cm}$ (Fig. 3).

\section{Measuring site on carcasses}

In reindeer and sheep, measurements were carried out on hanging carcasses. The detector was placed inside the carcass such that it pressed at right angles against the vertebral column in the pelvic cavity.

In cattle, measurements were performed on hanging sides of beef. The detector was placed on the caudal thigh musculature (m. semitendonosus and $\mathrm{m}$. semimembranosus).

\section{Results}

Series 1

Table 1 gives the estimated geometrical factors from measurements carried out in live reindeer, cattle, and sheep. The degree of uncertainty in determining the geometrical factor, at a confidence level of $95 \%$, was less than $7 \%$ for reindeer, less than $11 \%$ for cattle, and less than $8 \%$ for sheep. Table 2 shows the estimated geometrical factors for carcasses of reindeer, cattle, and sheep. Measuring time was 30-60 sec.

Determination of background radiation. The determination of background radiation was carried out at locations selected for measurements. The background radiation was the major factor affecting the detection limit. Detection limits for live monitoring va- 


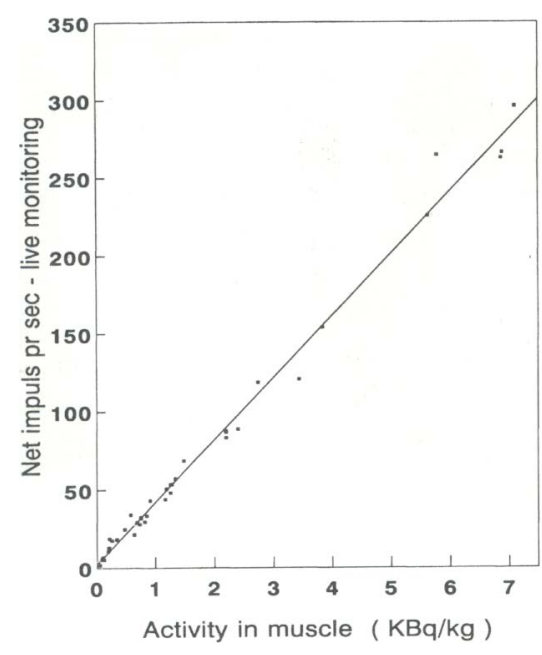

Figure 4. Relationship between impulses per sec measured in 38 live sheep and levels of radioactive caesium in corresponding meat samples (Series 2).

ried between $50-200 \mathrm{~Bq} / \mathrm{kg}$ in areas the ground deposition between 5 and $200 \mathrm{kBq} / \mathrm{m}^{2}$.

Shielding factor. The shielding factor for cattle and sheep was estimated from measurements of live animals with very low activity levels. For cattle the shielding factor was $0.67 \pm 0.09$ and for sheep $0.85 \pm 0.02$.

\section{Series 2}

As the trials were carried out on a relatively small number of animals, several more measurements were subseqently performed to increase the reliability of the method. A very strong relationship was documented between measurements of live animals and meat samples (Fig. 4, $r=0.99, p<0.0001$ ).

The average geometrical factor for the 38 sheep in this trial was $22.6 \pm 1.5$ (Table 3 ). Fig. 5 shows the variation in geometrical factors seen in relation to the level of radioactive caesium in the animal.

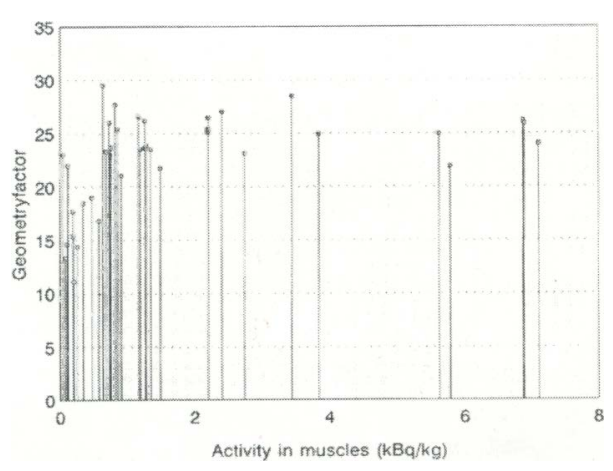

Figure 5. Variation in geometrical factors seen in relation to the level of radioactivity in the animal (Series 2).

The geometrical factors for in vivo measurements in current use (1993) for unshorn sheep are given in Table 4.

\section{Discussion}

\section{General considerations}

Although the initial method was based on a relatively small number of animals from the "crisis" year of 1986, the method nevertheless proved to be satisfactory under practical field conditions. The method was taken into full use in the slaughter season in the autumn of 1987.

The results showed that it was possible to measure radioactivity levels directly in live animals and carcasses with a relatively high degree of accuracy. It thus proved feasible to determine the activity of ${ }^{137} \mathrm{Cs}$ and ${ }^{134} \mathrm{Cs}$ in live reindeer, cattle and sheep at the time of slaughter.

The experimental in vivo measurements and testing of the methodology were carried out under controlled conditions. A very high cor- 
relation was found between live monitoring and meat samples (Series 2).

Normally the uncertainty proved to be less than $10 \%$.

In sheep with radioactivity levels of less than $400 \mathrm{~Bq} / \mathrm{kg}$, the degree of uncertainty could exceed $10 \%$. This was observed in series 2 , but even then the in vivo measurements seldom differed by more than $\pm 100 \mathrm{~Bq} / \mathrm{kg}$ at these low activity levels (Fig. 5).

The reliability of the method is influenced by the crystal. Each crystal must be calibrated individually.

The difference in the half life of the 2 caesium isotopes also leads to changes in the geometrical factor with time. During the period 198693, it has been necessary to adjust the geometrical factor due to the changing relationship between the activities of the 2 caesium isotopes (halflife for ${ }^{137} \mathrm{Cs}=30.1$ years, halflife for ${ }^{134} \mathrm{Cs}=2.1$ years). The geometrical factors for in vivo measurement 1993 for unshorn sheep are given in Table 4. Furthermore, for sheep, the geometrical factor was different for shorn and unshorn animals (Resell 1989).

Results of a control program involving continuous monitoring of meat samples from live monitored animals has shown an acceptable precision. More than $95 \%$ of the samples had less than $15 \%$ difference between the live monitoring results and laboratory measurements of the meat samples.

Growing animals will change in size, and therefore also in geometry, depending on the time of the year when measurements are performed (for example, a lamb in the spring compared with the same lamb in the autumn). Accordingly it was necessary to estimate different geometrical factors for summer, and autumn/winter. The geometrical factors have been estimated on the basis of the situation existing in Norway as regards, animal species, breeds, and levels of deposition. In other countries, a different situation with regard to animal breeds and deposition levels may influence the choice of procedure for measuring radioactivity levels in live animals.

In Ireland the measurements were done by placing the scintillation detector in contact with the fleshy part of the sheep's rump and performing one $50 \mathrm{sec}$. count. Four background measurements were made on each farm by holding the detector next to the operator's rump and counting for $50 \mathrm{sec}$. (Colgan et al. 1989).

\section{Usefulness of the method}

The sheep population in Norway is approx. 2.2 million, of which about $60 \%$ are slaughtered in the autumn. When the Chernobyl reactor accident occurred in April 1986, rapid methods for the measurement of radioactive caesium in live animals were not available.

During the slaughtering season in the autumn of 1986 , it was necessary to divide Norway into zones relative to the degree of contamination of the sheep. The delinitation of zones had to be based on measurement of radioactivity in samples of meat from slaughtered sheep. Later on during the same autumn, zones were also established for reindeer and cattle. (Johanson \& Brynildsen 1988).

Already in 1987, the live motoring method was used to establish zones.

The development and implementation of counter measures, combined with measurements of levels in live animals, made it possible to sort large amounts of valuable meat for human consumption. During the period 1986 through 1991 the monetory value of the meat which otherwise would have been discarged because of too high activity levels, has been estimated to be about $1 \times 10^{9}$ NOK. Annual programmes comprising the random sampling of meat specimens from the slaughter houses have served to check that the delinitation of 
zones based on live monitoring radioactivity in live animals, has been adequate (unpublished data from the Ministry of Agriculture (Anon)).

The present method for measurement of radiocaesium levels in live animals has become the main tool for definition of zones and implementation of countermeasures in Norway after the Chernobyl accident.

When measurements were carried out on the carcasses hanging on the slaughter line, this method was rapid enough to sort out carcasses unfit for human consumption.

\section{Acknowledgement}

We thank Dr. O. Sandvik and Dr. B. Underdal for helpful discussions and critical comments to the manuscript, and Ms. A. A. Sørli for help and technical assistance during the study.

This work was supported by the Norwegian Ministry of Agriculture, to whom our thanks are due.

\section{References}

Anderson-Sørlie A, Strand P, Selnes T: Brukerveiledning for Canberra serie 10-1992:6. (Instructions for use for the Canberra series 10-1992:6). Working document issued by the Norwegian Radiation Protection Authorithy. 1992.

Anonymous: Archives of the Ministry of Agriculture, Divisions of Veterinary Services, Oslo.

Colgan PA, Duffy JT, Madden JS, O'Grady J, Hone $C P$, Daly $L E$ : Radiocaesium Activity in Mountain Sheep. A preliminary study in County Donegal, Ireland by in vivo measurement. Irish J. of Agric. Res. 1989, 28, 141-151.

Johanson L, Brynildsen L: Radiological consequences of Chernobyl fallout in Norway. Revue Sclentif. Techn. Office International Epizooties. 1988, 7, 115-127.

Resell $J E$ : Verknad av klipping på utskiljingsfart av radiocesium på sau. (Effect of shearing on rate of excretion of radiocesium from contaminated sheep). Thesis. Agricultural University of Norway. Ås. 1989.
Strand P, Brynildsen LI: Rapid method for live monitoring of cesium activity in sheep, cattle, and reindeer. IAEA-SM-306/37P. Extended synopsis. Proc. Int. Symp. Environmental Contamination Following a Major Nuclear Accident. Vienna, October 1989.

Strand P, Brynildsen LI, Harbitz O, Tveten U: Measures introduced in Norway after the Chernobyl accident. IAEA-SM-306/36. Proc. Int. Symp. Environmental Contamination Following a Major Nuclear Accident, Vienna, October 1989.

\section{Sammendrag}

Hurtigmetode for bestemmelse av radiocesium i levende dyr og slakteskrotter.

Nedfallet av radioaktivt cesium etter reaktorulykken i Tsjernobyl 26. april 1986 førte tildels til sterk forurensning av norske landbruksprodukter. Dette gjaldt spesielt for småfe-, storfe- og reinsdyrkjøtt.

For å få oversikt over forurensningssituasjonen og for å kunne overholde myndighetenes tiltaksgrenser for radiocesium i næringsmidler ble Norge delt inn i soner mht høstslaktingen 1986. Soneinndelingene gjaldt spesielt for kjøtt av småfe, storfe og reinsdyr. Tiltak ble satt i verk for å redusere nivået av radioaktivt cesium i dyrene før slakting.

Soneinndelingene høsten 1986 ble foretatt ut fra målinger på kjøttprøver. På grunn av manglende muligheter for måling av radiocesiuminnhold før slakting ble sauekjøtt for 80 mill. NOK ikke godkjent for humant konsum.

I løpet av vinteren 1986/87 ble det utviklet en metode for måling av radioaktivt cesium på levende dyr og på slakteskrotter. Måleutstyret var en bærbar mangekanal analysator med en natriumjodid scintillasjonsdetektor.

Geometrifaktorer (forholdet mellom nivåt av radioaktivt cesium målt i kjøttprøven og impulser pr sekund målt på det levende dyret) ble bestemt for alle dyreslagene. Det var en meget god korrelasjon $(\mathrm{r}=0,99)$ mellom målt aktivitet $\mathrm{i}$ levende dyr og nivået av radiocesium i kjøttprøver. Denne hurtigmetoden for måling av radioaktivt cesium i levende dyr ble raskt tatt i bruk under feltforhold og dannet i Norge grunnlaget for soneinndeling, tiltak og bestemmelse av slaktetidspunkt.

(Accepted August 29, 1994).

Reprints may be requested from: L. Brynildsen, The Ministry of Agriculture, Division of Veterinary Services, P.O. Box 8007, Dep., N-0030 Oslo, Norway. 